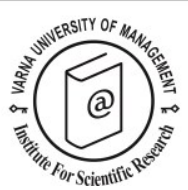

\title{
Costa, C., Panyik, E. and Buhalis, D. (Eds.) (2014). European tourism planning and organisation system: the EU member states. Bristol: Channel View Publications.
} ISBN-13: 978-1-84541-433-0 (pbk). 468 pages.

\author{
Reviewed by Xing Huibin ${ }^{1}$
}

Received: 12/09/2014

1 Department of Tourism, Hebei University, 180 Wusi East Road, 071002 Baoding, China; tel: +86 13932277819; email: xinghuibin@gmail.com

(C) 2015 Varna University of Management. All rights reserved

Citation Costa, C., Panyik, E. and Buhalis, D. (Eds.) (2014). European tourism planning and organisation system: the EU member states. Bristol: Channel View Publications. ISBN-13: 978-184541-433-0 (pbk). 468 pages, Reviewed by Xing Huibin, European Journal of Tourism Research 10 , pp. $142-144$

Nowadays, EU is still trapped in the unprecedented debt crisis and the subsequent uncertainties in the Euro zone. In spite of the hardship, EU tourism keeps vigorous and continuously holds the biggest global share in both tourist arrival and tourism revenue. In 2013, EU member states received 432.7 million of international tourists with a growth of $5.0 \%$, accounting for $39.8 \%$ of arrivals worldwide. Meanwhile, these states obtained 303.4 billion Euros with an increase of $3.4 \%$, sharing $34.8 \%$ of the global receipts (UNWTO, 2014). Given various challenges, EU should design a new tourism planning and organisation system to further enhance its competitiveness (Costa, Panyik, \& Buhalis, 2013), based on the comparison of these EU member states. Nevertheless, the previous publications have not delivered from a holistic perspective, though some literatures concern certain member states (Costa, Panyik, \& Buhalis, 2013). Therefore, this book is a welcomed addition to the academic field and caters for the increasing attention on the tourism in EU.

The book begins with the study background from the perspectives of both industry and academia (Chapter 1). Meanwhile, this chapter proposes a comparative framework to systematically analyse these EU member states, focusing on six key elements (actors, territory, economics, policies, methods, and vision). As an echo, a new EU tourism planning and organisation system is established from a product perspective at the end, based on the comparison and empirical analysis (Chapter 29). The core of the book is organised into five parts spanning from chapters 2 to 28 authored by 52 scholars, concentrating on the $27 \mathrm{EU}$ member states (by 2012). Interestingly, to facilitate the comparison, each chapter in the five parts adopts a similar structure and begins with the evolution of tourism in that country. Then, tourism planning and organisation is illustrated respectively at the national, 
Costa, C., Panyik, E. and Buhalis, D. (Eds.) (2014). European tourism planning and organisation system: the EU member states. Bristol: Channel View Publications. ISBN-13: 978-1-84541-433-0 (pbk). 468 pages, Reviewed by Xing Huibin, European Journal of Tourism Research 10, pp. 142-144

regional, and local levels. After that, the key issues, challenges, and trends are identified and critically analysed. Finally, a conclusion is given to summary the chapter.

Part 1 focuses on the five member states in Northern Europe. Chapter 2 tells a story of how Danish tourism has been morphing from ugly duckling into beautiful swan by the national strategy "Our Journey", in spite of limitation and challenges. Similarly, England tourism also experiences the transformation from being neglected to be strategised, shown intensively at the tourism policies for the major sporting events, such as London 2012 Olympic Games (Chapter 3). Chapter 4 reveals that Finnish tourism strategy gives more attention to the wide participation from various stakeholders, intertwining with the public and private parts. As for Irish tourism, given the environmental changes and challenges, it should strengthen branding and marketing, and expand new markets to enhance its tourism competitiveness and innovation (Chapter 5). In Sweden, tourism organisations mainly handle three issues, specifically including the branch of activity, economic and political ideas and value systems, and the legitimacy in the tourism organisations (Chapter 6).

Part 2 turns to Eastern Europe. Chapter 7 introduces the multi-side management structure of tourism in Bulgaria and illuminates its current issues from four aspects: coordination and cooperation among different organisations, tax system, market segmentation, and organisation setting of tourism authorities. Next, Estonia tourism is presented mainly from tourism evolution, tourism policy, tourism organisation, and tourism marketing (Chapter 8). Chapter 9 introduces the three kinds of institutions in Latvia handling the planning and management of tourism, specifically including NGO and advisory institutions, policy making institutions, and executive institutions. Chapter 10 gives a brief introduction of Lithuania tourism. It outlines the main characteristics of the formation and management of tourism policy as well as its strengths and weaknesses in Lithuania.
Chapter 11 depicts a whole profile of the organisational structure of tourism management in Romania. In addition, the issues and tendencies in tourism policy are concerned in this chapter.

Part 3 covers six countries in Central Europe. Austria tourism is described in Chapter 12. In this chapter, some specific cases are used to explain the tourism organisations and policies in Austria. Chapter 13 illustrates the roles and responsibilities of tourism organisations in the Czech Republic as well as the main tourism strategy. Next, Chapter 14 provides a detailed overview of Germany tourism by an extensive use of tables. Moreover, this chapter also analyses the characteristics and issues of tourism planning and organisation in Germany at different management levels. Chapter 15 concerns the transformation of tourism policy in Hungary from central planning to multi-level destination management. Meanwhile, the organisational structure and the limitation in tourism are also involved. Chapter 16 concentrates on the three-dimensional organisation structure of tourism in Poland as well as the different roles of the management entities. Then, the tourism organisation system in Slovakia is addressed from an attributive perspective (Chapter 17). In addition, a newly accepted tourism code is introduced as the countermeasure to solve the problems in the organisation structure.

Part 4 concerns Southern Europe with six chapters. Chapter 18 reviews the tourism organisation system consisting of the public organisations, private enterprises, and professional associations. Meanwhile, three tourism strategies are stressed in the process of planning and implementation. Next, Chapter 19 analyses the position of tourism sector in Greece and depicts its complicated organisation structure. In addition, the issues and trends are discussed based on a SWOT analysis. Chapter 20 gives the tourism profile of Italy and introduces its three-dimensional organisation structure. Besides, this chapter discusses the tourism strategies and projects involved as a response to the current challenges. In Chapter 21, a dynamic perspective of history is used to analyse 
Costa, C., Panyik, E. and Buhalis, D. (Eds.) (2014). European tourism planning and organisation system: the EU member states. Bristol: Channel View Publications. ISBN-13: 978-1-84541-433-0 (pbk). 468 pages, Reviewed by Xing Huibin, European Journal of Tourism Research 10, pp. 142-144

Malta tourism and its organisation: past, present, and future. Interestingly, this chapter also discusses the opportunities and challenges from EU membership, especially on airline dependency, migrant worker, education, and tourism brand. Chapter 22 systematically overviews the evaluation process of tourism organisations in Portugal from complexity to simplicity. At the same time, the tourism profile and the current issues are addressed in this chapter. Chapter 23 focuses on Slovenia tourism from three aspects: tourism system, tourism strategy, and tourism evaluation. Meanwhile, the new tourism products in Slovenia are introduced, namely thermal spas, Alpine tourism, Mediterranean tourism, and cultural tourism. Chapter 24 presents the planning and organisation structure of tourism in Spain characterised by a high decentralisation. In addition, this chapter reveals the practical need for cooperation policies and new management approach in Spanish tourism.

The final section "Western Europe" comprises four chapters and the conclusion as the fifth chapter. Chapter 25 concentrates on the tourism organisations and strategies in Belgium from a regional perspective. Moreover, the development background of Belgian tourism is also analysed as well as the links with EU. Chapter 26 distinguishes these tourism planning and organisations in France at different administrative levels. This chapter also introduces the main products of French tourism and discusses its sustainable issues. Next, the tourism governance and policy in Luxembourg are concerned in Chapter 27. Besides, this chapter depicts its tourism profile in tourist demand and tourism products. Chapter 28 reviews the evaluation of Dutch tourism in a historical viewpoint, mainly covering three fields: policy, organisation, and strategies.

As a whole, this book is an exciting delivery, clarifying the tourism planning and organisations in EU from a perspective of member state. In addition, it is much devoted to exploring and resolving the tourism issues in these states. Moreover, the book not only integrates abundant data and practical materials in the text, but also adds a lot of schematisations (107 figures and 73 tables) as the auxiliary for clearer explanations. These contexts will surely stimulate future studies and research on this field.

Moreover, the book is timely and needed especially under the current crisis in Europe and addresses many points of concern worth the investment of attention in spite of being lengthy. This book can be read as a valuable resource for diverse audiences to raise knowledge and expand scopes on European tourism. As the editors state at the end, the book is an excellent indication of European tourism planning and organisations for both undergraduate and postgraduate students interested in knowing more about tourism planning in Europe. Meanwhile, it also appeals to academics, researchers and tourism practitioners wishing to engage in the theoretical principles and the conceptualisation of planning and organisation systems.

If the editors were to consider a revised edition in the future, I would recommend a separate chapter or additional content in the conclusion focusing on the comparison by region or state. In addition, if the figures and maps included in the book could be printed in colour with high resolution, the illustration effects would be improved so as to offer reader with better understanding. Nevertheless, given the limitation of space and a huge amount of states involved, it is difficult to include all research topics into a single book. Overall, this book is an excellent work of European tourism studies and is definitely worthwhile to concern.

\section{References}

Costa, C., Panyik, E. \& Buhalis, D. (Eds.) (2013).Trends in European Tourism Planning and Organisation. Bristol: Channel View Publications.

UNWTO. (2014). Tourism highlights. Madrid: UNWTO. 